\title{
Images in Infectious Diseases in Obstetrics and Gynecology
}

\author{
Section Editor: David E. Soper, M.D.
}

\section{Microscopy of the Bacterial Flora on Fresh Vaginal Smears}

\author{
Gilbert G.G. Donders \\ Department of Gynecology and Obstetrics, Katholieke \\ Universteit Leuven, Belgium
}

$\mathrm{V}$ aginal bacterial flora can be studied by microscopy of fresh vaginal fluid or of a fixed, stained smear. Classifying the flora by microscopy of fresh smears of vaginal fluid allows the pathology to be approached in a way other than by application of Nugent et al.'s criteria ${ }^{1}$ for Gram-stained specimens. Therefore, it may enable a more diverse and accurate assessment of the risk of preterm birth and other complications. ${ }^{2}$

The classification is based on the relative quantities of lactobacillary morphotypes present. If lactobacilli of variable size predominate, the flora is considered normal (lactobacillary grade I Fig. 1). Sometimes, this grade-I flora leads to production of excessive amounts of lactate ${ }^{3}$ and acidity due to hydrogen peroxidase activity, ${ }^{4}$ even causing lethal damage to the epithelial cells (epitheliolysis). The bare nuclei of these torn cells can be seen, along with the debris of their cellular cytoplasm and with numerous lactobacilli (Fig. 2). Care must be taken to differentiate the cellular debris from coccoid bacteria and not to misinterpret the bare epithelial nuclei as leukocytes.

Lactobacillary grade III is an intermediate flora, with a mixture of lactobacilli and other morphotypes, usually coccoids. If the lactobacillary morphotypes still outnumber the other bacteria, this is called lactobacillary grade IIa (Fig. 3); if the lactobacillary morphotypes are less abundant than the other morphotypes, the term used is grade IIb (Fig. 4). Although grade II will partly overlap with the intermediate group of the bacterial vaginosis score according to Nugent et al. (score 4-6), it is certainly not identical to that group.

Lactobacillary grade II indicates complete disruption of the normal vaginal flora: other bacteria have completely overgrown the lactobacilli, which are no longer visible. The most obvious condition that would cause these lactobacilli to disappear is bacterial vaginosis, with its pathognomonic granular background appearance due to large numbers of anaerobic bacteria (Fig. 5) and the clue cells. It is not wise, however, to call every condition devoid of lactobacilli bacterial vaginosis. A search for trichomoniasis and other sexually transmitted diseases is also warranted. ${ }^{5}$ If the grade-III flora consists of coarse, coccoid bacteria or is accompanied by numerous parabasal epithelial cells and increased vaginal leukocytosis (Fig. 6), the condition certainly does not correspond to the anaerobic condition Gardner and Dukes 6 and Amsel et al. ${ }^{7}$ had in mind when discussing the clinical diagnosis of bacterial vaginosis. Again, it is unclear in which $\mathrm{Nu}$ gent score this group belongs; most probably you would find it dispersed among the intermediate (score 4-6) or bacterial vaginosis (score 7-10) groups. Cultures often grow streptococci and gramnegative bacteria of enteric origin. We propose to call this condition "aerobic vaginitis," a clinical entity clearly distinct from bacterial vaginosis, rather to be seen as a lesser form of "desquamative vaginitis." 8,9

\section{REFERENCES}

1. Nugent RP, Krohn MA, Hillier SL. Reliability of diagnosing bacterial vaginosis is improved by a standardized method of Gram's stain interpretation. J Clin Microbiol 1991;29:297-301.

2. Donders GGG. Bacterial vaginosis. Screen and treat? (Editorial). Eur J Obstet Gynecol 1998, in press.

3. Donders GGG, Desmyter J, Vereecken A, Vaginitis. (Letter) N Engl J Med 1998;338:1547-1548.

Images in Infectious Diseases in Obstetrics and Gynecology presents clinically important visual images that a practitioner in women's health might encounter. If you have a high-quality color or black-and-white photograph or slide representing such an image that you would like considered for publication, send it with a descriptive legend to David E. Soper, MD, Department of Obstetrics and Gynecology, Rush-Presbyterian-St. Luke's Medical Center, 1653 West Congress Parkway, Chicago, IL 60612-3833.

Images is made possible through an educational grant from Pfizer, Inc. 

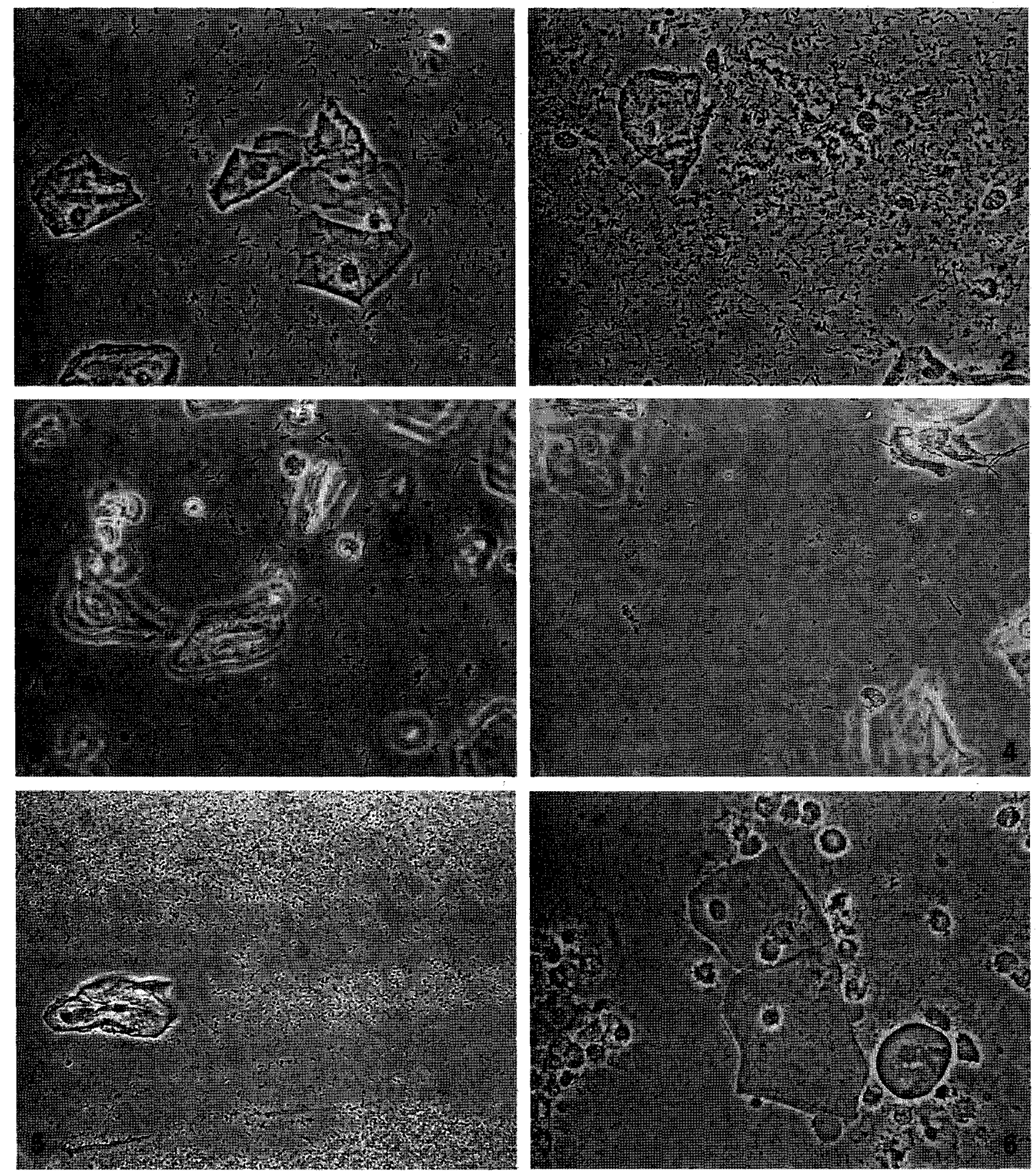

4. Donders GGG, De Wet GH, Hooft P, Desmyter J. Lactobacilli in Pap smears, genital infections and pregnancy. Am J Perinatol 1993;10:358-361.

5. Eschenbach DA, Davick, PR, Williams BL, et al. Prevalence of hydrogen peroxide-producing Lactobacillus species in normal women with bacterial vaginosis. $\mathrm{J}$ Clin Microbiol 1989;27:251-256.

6. Gardner HL, Dukes CD. Haemophilus vaginalis vaginitis. A newly defined specific infection previously classified 'Nonspecific' vaginitis. Am J Obstet Gynecol 1955;69:962-976.

7. Amsel R, Totten PA, Spiegel CA, Ghen K, Eshenbach DA, Holmes KK. Nonspecific vaginitis. Diagnostic criteria and microbial and epidemiological associations. Am J Med 1983;74:14-22.

8. Gardner HL. Desquamative inflammatory vaginitis: a newly defined entity. Am J Obstet Gynecol 1968;102: 1102-1105.

9. Sobel JD. Desquamative inflammatory vaginitis: a new subgroup of purulent vaginitis responsive to topical $2 \%$ clindamycin therapy. Am J Obstet Gynecol 1994;171: 1215-1220. 


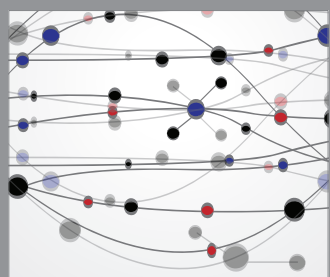

The Scientific World Journal
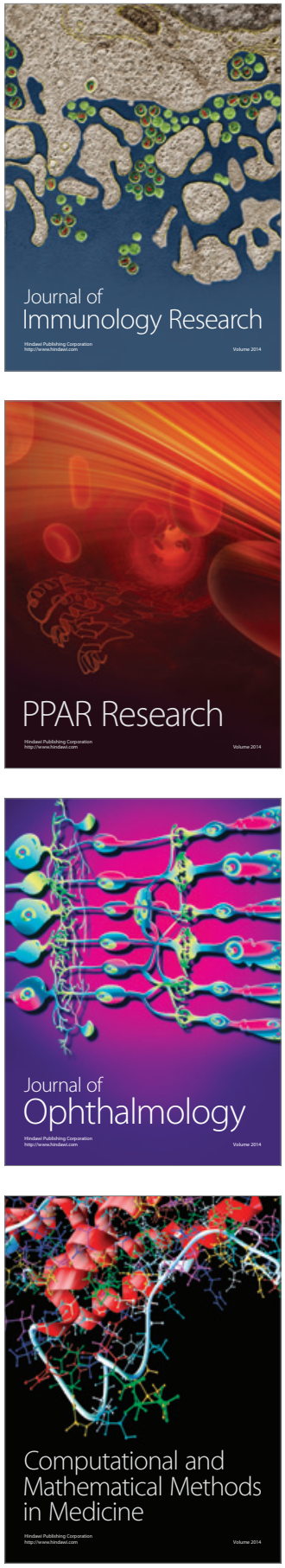

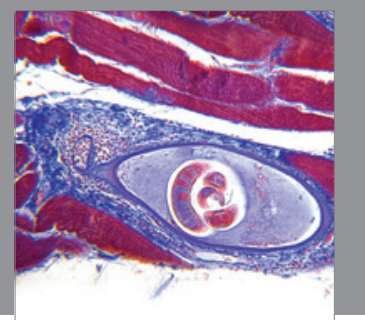

Gastroenterology

Research and Practice
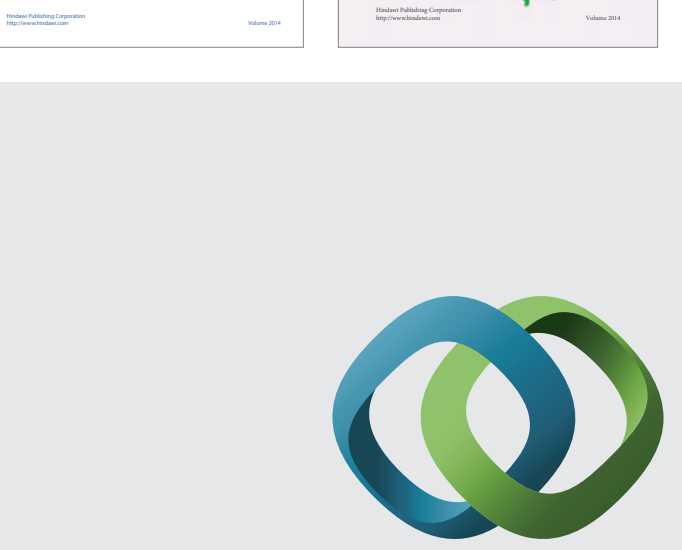

\section{Hindawi}

Submit your manuscripts at

http://www.hindawi.com
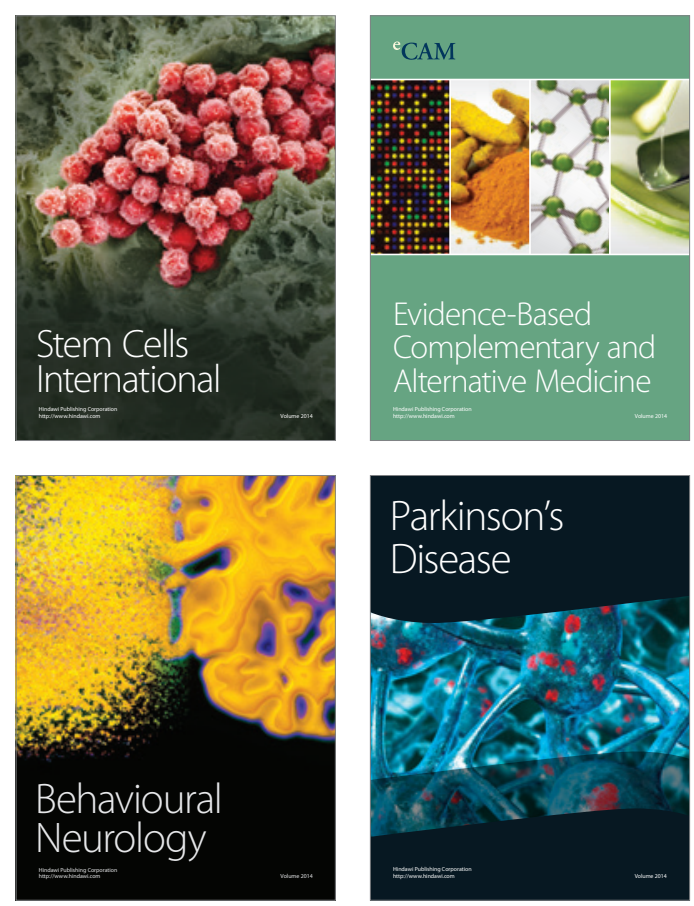

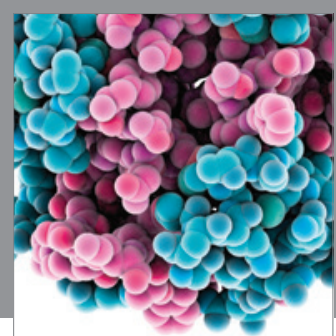

Journal of
Diabetes Research

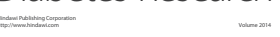

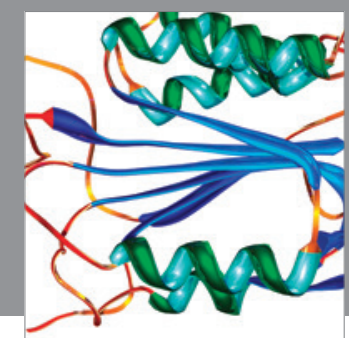

Disease Markers
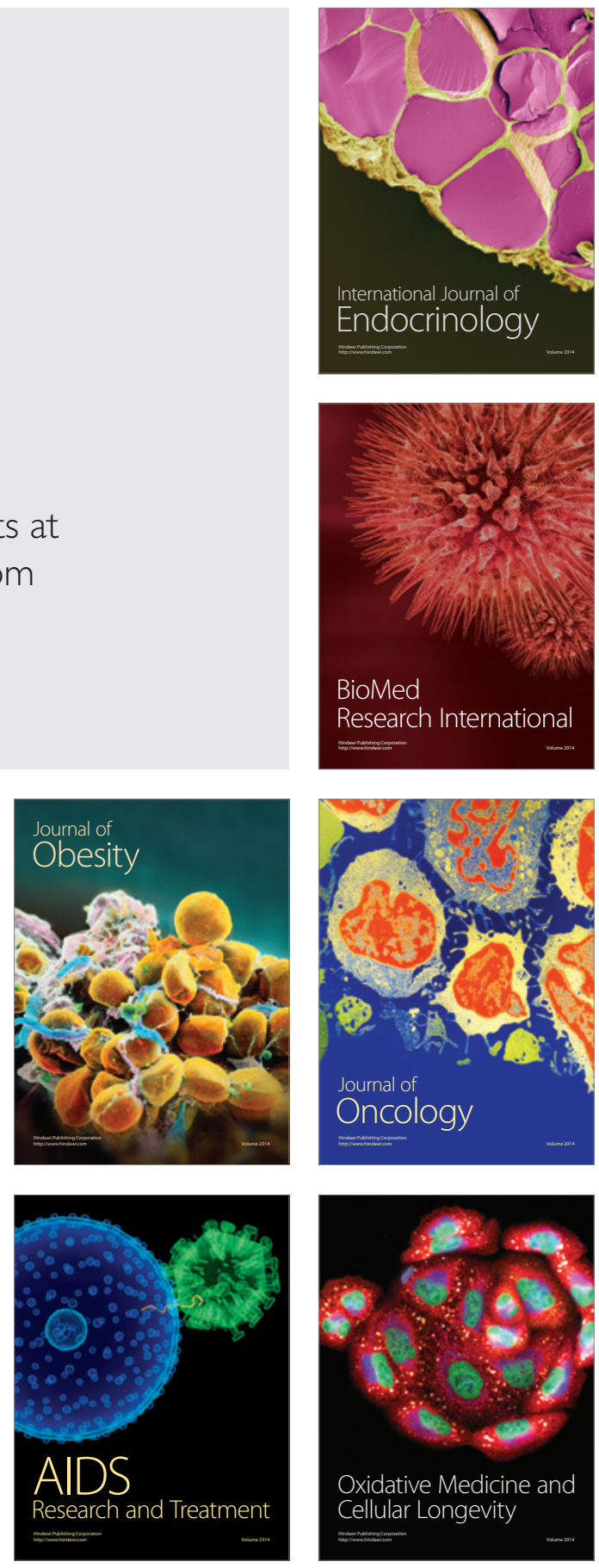